\title{
ECONOMICS
}

\section{REGIONAL DISPARITY, TRANSITIONAL DYNAMICS AND CONVERGENCE IN CHINA}

by

\section{Tsun Se Cheong}

and

Yanrui Wu

Business School University of Western Australia 


\title{
REGIONAL DISPARITY, TRANSITIONAL DYNAMICS AND CONVERGENCE
}

\section{IN CHINA}

\author{
Tsun Se Cheong and Yanrui Wu \\ Economics \\ Business School \\ University of Western Australia \\ September 2012
}

DISCUSSION PAPER 12.23

\begin{abstract}
Most studies of regional inequality in China are based on provincial level data with a few papers focusing on intra-provincial regional inequality. The objective of this study is to fill the void in the literature by using county-level data which cover 1485 counties and county-level cities in 22 provinces for the period of 1997-2007. This paper makes several contributions to the literature. First, the disparity between city and county subgroups within each province is examined. Second, the transitional dynamics of regional inequality are investigated for different spatial groups using the Markov transition matrix approach. Third, the stochastic kernel technique is applied to investigate convergence of the county-level units as a whole. The findings in this paper show high persistence in many spatial groups. Thus the poor county-level units may remain relatively poor over time. The model provides very little evidence of convergence to the mean income in various spatial groups. The empirical analysis highlights differences in transitional dynamics between cities and counties.
\end{abstract}

Key words: China, Markov transition matrix, county-level units, inequality JEL codes: O11, O18, O53, R11

Acknowledgements: The authors would like to thank Yuk Shing Cheng, James Laurenceson and Xiaowen Tian for their comments on an earlier draft. We also thank the participants of the $24^{\text {th }}$ Annual Conference of the Chinese Economics Society Australia (CESA) which was held in the Australian National University (ANU) and a brownbag economics seminar at UWA Business School for their suggestions. All remaining errors are ours. 


\section{Introduction}

Whether regional income converges or not has implications for regional inequality. Some researchers used county-level data to investigate the convergence in regional income in the US and UK (Bishop and Gripaios, 2006, Higgins et al., 2006) using. However, convergence studies using county-level data in China are rare and most of the studies are based on provincial level data. The studies which are based on county-level data are restricted to the provinces or regions in the eastern zone, or only the cities. Thus the possibilities of convergence of the county-level units, namely counties and county-level cities, in many other parts of China still remain largely unknown. This paper contributes to the literature by exploring future evolution of inequality and the underlying transitional dynamics using county-level data. Convergence analyses are conducted for the provinces and other spatial groupings individually. In addition, the technique of stochastic transition kernel has been adopted in this study to investigate the possibility of convergence for China.

Given the huge irregularity in the economic development among inland and coastal regions, economic zones and provinces the underlying transitional dynamics can be very different. Hence, research on convergence should not be restricted to the national level. It is important to study income distributions within inland and coastal regions, economic zones, as well as the provinces to allow a more in depth and accurate analysis. Therefore, the studies of convergence in this paper are carried out for various spatial groupings. Moreover, the county-level data is divided into the city-only and county-only datasets and convergence analyses are performed for these two datasets separately so as to reveal the different nature of transitional dynamics.

This paper is organized as follows. Section 2 presents the background information about economic convergence and also provides a review of convergence studies in China. Section 3 examines the methods, whereas Section 4 introduces the data used in this paper. Section 5 presents the results of the analyses. Section 5.1 reports the empirical findings for various spatial groupings. Section 5.2 presents the results of convergence analyses based on the city-only and county-only datasets. Section 5.3 reports the results of the analyses of Markov transition matrices conditional on spatial factor and administrative status. This paper concludes with Section 6 .

\section{The existing literature}

The study of income convergence continues to be a popular topic in development economics and many theories have been proposed. According to Kuznets (1955), income inequality increases in the initial phase of industrialisation and it then reaches a peak and starts to decline. This pattern of changes is now popularly called the Kuznets curve which defines an inverted-U relationship between inequality and economic development. The work of Kuznets inspired Williamson (1965) who found that there is an inverted-U relationship between regional inequality and economic development. Alonso (1980) also argued that regional 
inequality increases with economic development initially and the trend reverses after a point of inflection is reached.

Another major contribution to the study of convergence was made by Solow (1956) and Swan (1956). The neoclassical models of Solow and Swan predict that conditional convergence is possible. Poor economies tend to grow faster than their rich counterparts. The endogenous growth theory proposed by Romer (1986) and Lucas (1988) suggests that convergence is not guaranteed and trends in inequality can persist. The new economic geography theory combines economic geography and traditional location methods (Krugman, 1991a, Krugman, 1991b, Krugman and Venables, 1995, Fujita et al., 1999). Using models incorporating labour migration, Krugman (1991b) proposes that a core-periphery pattern can emerge and inequality can persist over time. Using models of vertically-linked industries, Krugman and Venables (1995) suggest that if labour is immobile, then the concentration of industries in some regions can lead to an increase in wages in these regions, which can reduce the effect of agglomeration. A core message from this line of research is that economic convergence can be affected by many factors and therefore is not a certainty.

In the empirical literature, many different approaches are used. Some of the studies are based on time series techniques such as the cointegration and unit root tests (Bernard and Durlauf, 1995, Oxley and Greasley, 1995, Bernard and Durlauf, 1996, Hobijn and Franses, 2000, Lim and McAleer, 2004, Pesaran, 2007). Other studies follow the concepts of $\sigma$-convergence and $\beta$-convergence (Barro and Sala-I-Martin, 1991, Barro and Sala-I-Martin, 1992). A third strand of the literature adopts the distribution dynamics approach (Quah, 1993, Quah, 1996a, Quah, 1996c).

Several studies of convergence in China used the time series approach. In general it is found that economic reforms have led to divergence of regional income (Zhang et al., 2001, Pedroni and Yao, 2006, Lau, 2010, Westerlund et al., 2010). The existing literature also presented evidence of club convergence (Zhang et al., 2001, Liu and Wang, 2010, Matsuki and Usami, 2011). There is also a large pool of literature which adopts the concepts of $\sigma$-convergence and $\beta$-convergence. The findings are very mixed. ${ }^{1}$ However these methods have been criticized for ignoring the dynamic changes in income distribution (Quah, 1993). To overcome this shortcoming, the discrete Markov transition matrix and stochastic kernel technique have been adopted in the study of income distribution dynamics. Several papers were presented by Quah (1993, 1996a, 1996c). Since then, many researchers have employed this method (for example, Jones, 1997, Fingleton, 1999, Magrini, 1999, Rey, 2001, Bickenbach and Bode, 2003, Epstein et al., 2003, Li, 2003, Gallo, 2004, Le Gallo, 2004, Sakamoto, 2007, Bosker and Krugell, 2008, Geppert and Stephan, 2008, Sakamoto and Islam, 2008).

\footnotetext{
${ }^{1}$ Examples focusing on the concept of $\sigma$-convergence include Lyons (1991), Chen and Fleisher (1996), Tsui (1996), Raiser (1998), Zheng et al. (2000), Chang (2002), Li et al. (2008), Duan (2008), Zou et al. (2008), Zhou and Zou (2010). For the studies of $\beta$-convergence, see Chen and Fleisher (1996), Jian et al. (1996), Gunlach (1997), Raiser (1998), Tian (1999), Chen and Feng (2000), Choi and Li (2000), Dacosta and Carroll (2001), Yao and Zhang (2001a), Yao and Zhang (2001b), Cai et al. (2002), Yao and Zhang (2002), Weeks and Yao (2003), Wu (2004), Duan (2008), Hao (2008), Li and Xu (2008), Zou et al. (2008), Villaverde et al. (2010), Gries and Redlin (2011), Marti et al. (2011). For more detailed literature reviews, see Wu (2004) and Cheong (2012).
} 
It has also been applied to Chinese data in several papers which are reviewed here.

$\mathrm{Li}$ (2003) found a small reduction in income disparity across 30 Chinese provinces and strong evidence of convergence within each economic zone. Pu et al. (2005) investigated the spatial-temporal dynamics of regional convergence for the county-level units in Jiangsu province over the period 1978-2000. They concluded that a region has the tendency to move to a higher income group if it is surrounded by rich regions and it has the tendency to move to a lower income group if it is surrounded by poor regions. This view is supported by He and Zhang (2007). Sakamoto and Islam (2008) argued that China's distributional dynamics in the pre-reform period and post-reform period are very different. Villaverde et al. (2010) also showed that, over the period 1978 to 2007, the persistence in the ranking of income levels was very high. Zhou and Zou (2010) examined convergence using prefecture- and county-level city data, and found that the shape of the distribution of GRP per capita for all the cities changed between 1995 and 2004. In general the findings in the existing literature imply that convergence is not possible for the whole nation, but there is evidence of club convergence in different spatial groupings. It is also worth noting that nearly all of the studies are based on provincial level data. Therefore, the distribution dynamics of the county-level units have not been examined thoroughly.

\section{Analytical Framework}

The distribution dynamics approach is adopted in this study because it has several virtues. First, this approach does not merely focus on the study of income growth but also includes an analysis of the underlying income distribution. Second, it can clearly show the mobility of the county-level units. Moreover, it can predict the proportion of the entities in different income groups in a number of years ahead and even in the long run. This approach can be further divided into the discrete Markov transition matrix and the stochastic kernel techniques. The two methods are closely related to each other. The conventional Markov transition matrix approach is discussed first.

Relative income is assumed to follow a finite first-order Markov chain with stationary transition probabilities. First, a state space of $m$ non-overlapping states is defined $(i=1, \ldots m)$ and each state represents an interval of relative income values. Let $y_{r}^{t}$ be the relative income, which is measured by the ratio of the gross regional product (GRP) per capita of the county-level unit $r$ to the mean GRP per capita, at time $t$. If the sequence $\left\{y_{r}^{0}, y_{r}^{1}, \ldots\right\}$ satisfies the relation

$$
P\left\{y_{r}^{t+1}=j \mid y_{r}^{0}=i_{0}, y_{r}^{1}=i_{1}, \ldots, y_{r}^{t-1}=i_{t-1}, y_{r}^{t}=i\right\}=P\left\{y_{r}^{t+1}=j \mid y_{r}^{t}=i\right\}=P_{i j}
$$

for all intervals, states and county-level units, then it is called a discrete-time Markov chain process (Kemeny 
and Snell, 1976, Geppert and Stephan, 2008). Equation (1) implies that the probability for a county-level unit $r$ to move from state $i$ at time $t$ to state $j$ at time $t+1$ depends only on the county-level unit's state $i$ at time $t$ but not on states at previous points in time. If the transition probability, $P_{i j}$, is independent of $t$, then it is called a time stationary Markov chain.

The Markov chain process can be described as

$$
D^{t+1}=M \cdot D^{t}
$$

where $M$ is a $m \times m$ matrix of transition probabilities (that is, $P_{i j}$ ), $D^{t}$ represents distribution at time $t$, and $D^{t+1}$ represents distribution at time $t+1$.

$M$ assumes the following form.

$$
M=\left(\begin{array}{ccccc}
P_{11} & \cdot & \cdot & \cdot & P_{1 m} \\
\cdot & & \cdot & & \cdot \\
\cdot & \cdot & P_{i j} & \cdot & \cdot \\
\cdot & & \cdot & & \cdot \\
P_{m 1} & \cdot & \cdot & \cdot & P_{m m}
\end{array}\right)
$$

$M$ can be constructed by calculating the elements, $P_{i j}$, in the matrix by

$$
P_{i j}=\frac{n_{i j}}{\sum_{j=1}^{m} n_{i j}}
$$

where $n_{i j}$ is the number of transitions from state $i$ to state $j . P_{i j}$ is the transition probability that a county-level unit will transit from state $i$ to state $j$ in next period.

By the repeated use of Equation (2), the distribution at any time $t+k$ can be derived.

$$
D^{t+k}=M^{k} \cdot D^{t}
$$

where $M^{k}$ is the product of $k$ identical transition matrices $M$.

If the transition matrix $M$ is irreducible (cannot be divided into closed subsets), while the transition probabilities are constant over time (that means all states are aperiodic) and if there are no absorbing states 
(recurrent), then the ergodic (steady state) distribution $D^{*}$ can be derived (Geppert and Stephan, 2008) as

$$
D^{*}=\lim _{k \rightarrow \infty} M^{k} \cdot D^{t}
$$

Ergodic distribution shows the distribution when $k$ is equal to infinity. Therefore, the ergodic distribution can be used to predict the future income distribution and explore the possibility of convergence in the future.

One major issue in the discrete Markov transition matrix approach is that the number of states of analysis and the grid values which are used to demarcate these states should be selected properly. A large number of states can provide more details in the distribution dynamics analysis. However, if the total number of states is too large, then it may render the Markov transition matrix approach infeasible. The selection of the grid values is also very important in the Markov transition matrix approach. There are two common approaches in the demarcation of the states. One approach is to set the grid values by uniform proportion so that initially the proportion in each state is more or less the same. Another approach is to set the grid values by fixed length so that each state has uniform interval length (except the two tails). The first approach is preferred if the sample size is small as this approach can ensure that adequate transition episodes are available for the analysis. The second approach is preferred for the comparison of results obtained from different subsets of data. For example, our sample of cities and counties can be divided into the city-only and county-only datasets, and the Markov chain analysis can then be implemented for each dataset individually. However, for the purpose of comparison, it is necessary to ensure that the same demarcation scheme is used for both the analysis of the city-only and county-only datasets. In this study, the sample size is large and hence it is not required to use the demarcation scheme that is based on uniform proportion. Besides, demarcation based on fixed intervals can also facilitate the comparison between different spatial groupings. Therefore, all the analyses in this paper are based on fixed interval demarcation.

Quah (2001) proposes the use of annual transitions in convergence analysis because in that way, the sample size can be larger and the estimation results more reliable. Thus, the Markov transition matrix analysis is based on the data of annual transition of relative GRP per capita in each county-level unit from 1997 to 2007. Each county-level unit is categorized into one of the five states according to its relative GRP per capita, which is the ratio of the GRP per capita to the mean GRP per capita of the sample considered (Table 1). The demarcation is selected to be close to the grid values used by $\mathrm{Li}$ (2003) in order to facilitate a comparison and small modification is made to ensure that the intervals in states 2, 3 and 4 have the same length. 


\begin{tabular}{lll}
\hline State & Income Group & Relative Income \\
1 & Lowest income & $<=0.5$ \\
2 & Low income & $>0.5$ and $<=0.85$ \\
3 & Average income & $>0.85$ and $<=1.2$ \\
4 & High income & $>1.2$ and $<=1.55$ \\
5 & Highest income & $>1.55$ \\
\hline
\end{tabular}

The stochastic kernel approach can be viewed as an extension of the discrete Markov transition matrix approach with a continuous infinity of relative income states. It can avoid the problem of demarcation. The kernel estimator is defined as follows:

$$
\hat{f}(x)=\frac{1}{n h} \sum_{i=1}^{n} K\left(\frac{x-X_{i}}{h}\right)
$$

where $K$ is the Epanechnikov kernel function, $h$ is the bandwidth, $n$ is the number of observations, and $X_{i}$ is an observed value of the variable. The bandwidth is chosen optimally according to Silverman (Silverman, 1986).

However, the estimation of the stochastic kernel density can be seriously affected if the income distribution has a long tail because under-smoothing may appear in areas with only a few observations, while over-smoothing may occur in areas with plenty of observations (Silverman, 1986). In China, income distribution tends to have a long right tail. In order to solve this problem, kernels of variable bandwidth can be employed to take the sparseness of data into consideration; and so the adaptive kernel method with flexible bandwidth is employed in this paper. A pilot estimate is computed first to determine the density and then the bandwidth is rescaled by a factor that reflects the density at that point (for details, see Silverman, 1986).

Suppose that the evolution of the income distribution is first order, time invariant, and further assume that the income distribution at time $t+\tau$ depends on $t$ only and not on any previous distribution, then the relationship between the distributions of relative GRP per capita at time $t$ and time $t+\tau$ can be represented as:

$$
f_{t+\tau}(z)=\int_{0}^{\infty} g_{\tau}(z \mid x) f_{t}(x) d x
$$

where $f_{t}(x)$ is the density function of the distribution of relative GRP per capita at time $t$, and $g_{\tau}(z \mid x)$ is the transition probability kernel which maps the income distribution from time $t$ to $t+\tau$, and $f_{t+\tau}(z)$ is the $\tau$-period-ahead density function of $z$ conditional on $x$. (see Johnson, 2000, Johnson, 2005, and Juessen, 
2009 for details). The ergodic density, given that it exists, can be found by:

$$
f_{\infty}(z)=\int_{0}^{\infty} g_{\tau}(z \mid x) f_{\infty}(x) d x
$$

where $f_{\infty}(z)$ is the ergodic density function.

The estimation outcome of the stochastic kernel approach is usually presented in contour map form, and the probability values of the transitions are not available for further examination. Therefore, the transitional dynamics of the stochastic kernel approach are more difficult to interpret than those from the discrete Markov transition matrix approach. Thus, this study is mainly based on the conventional discrete Markov transition matrix approach. However, the analysis of the stochastic kernel is also performed at the economy-wide level.

\section{Data}

The data used in this paper is based on the real GRP per capita of the counties and county-level cities in China from 1997 to 2007. It is made up of 1485 counties and county-level cities in every year. Only the data of the counties and county-level cities are included as the data of the city district is not available for some of the provinces. Therefore, the four municipalities, namely, Beijing, Tianjin, Shanghai, and Chongqing are not included in this study because the county-level units under these municipalities are mostly city districts.

The county-level units can be categorized into larger spatial groupings of four spatial levels, namely, the national, inland-and-coastal, economic zonal, and the provincial levels. Only 22 provinces are included in this study because the data of some provinces are not available for the whole period. The provinces are further grouped into four zones. The categorization of the zones is based on the 2006 China Statistical Yearbook (State Statistical Bureau, 2006).

- Eastern zone: Hebei, Jiangsu, Zhejiang, Fujian, Guangdong and Hainan. The municipalities of Beijing, Tianjin and Shanghai are excluded in this study. The province of Shandong is not included because of unavailability of data.

- Central zone: Anhui, Jiangxi, Henan, and Hunan. The provinces of Shanxi and Hubei are not included because of unavailability of data.

- Western zone: Inner Mongolia, Guangxi, Sichuan, Guizhou, Yunnan, Gansu, Qinghai, Ningxia and Xinjiang. The municipality of Chongqing is excluded in this study. The provinces of Shaanxi and Tibet are not included because of unavailability of data.

- North-eastern zone: Liaoning, Jilin and Heilongjiang. 
The GRP and population data are compiled from the Provincial Statistical Yearbook (State Statistical Bureau, 1998 - 2008a) for each province. However, where the data is unavailable, the data from the China Statistical Yearbook for Regional Economy (State Statistical Bureau, 2004 - 2008) and from the Provincial Yearbook (State Statistical Bureau, 1998 - 2008b) for each province is used. A few county-level units are not included because of incomplete information in the yearbooks. All the GRP data are adjusted by converting them into 1997 constant prices. Provincial deflator is used in deflation process because the deflator for each county-level unit is not available.

It should be noted that from time to time, there are some changes in the administrative divisions in China. The official website for Administrative Divisions in China (http://www.xzqh.org) is consulted so as to find out all the changes in administrative divisions from 1997 to 2007. One problem in data preparation is the change in boundary which can affect the measurement of the GRP per capita. The approach suggested by Fan (1995) is adopted to tackle this problem. The county-level units are aggregated when there are boundary changes amongst them. However, the aggregation is strictly limited to those with the same administrative status. Therefore, the counties can only aggregate with other counties and not county-level cities. The county-level units are deleted if there is a boundary change that involves both county and county-level city. The aggregation approach is quite common and Sakamoto and Fan (2010) also employ aggregation for the county-level units in their study on convergence so as to tackle the problem of data unavailability.

\section{Results and Discussions}

\subsection{Convergence within the nation}

The income distribution of county-level units in 1997, 2002 and 2007 is shown in Figure 1. It can be observed that income distribution has become increasingly unequal. The proportion in the income state 1 increased gradually in the study period. More and more county-level units experienced a decline in relative income and thus they migrated to the lowest income group. The evolution of income distribution in the future can be observed from the ergodic distribution. Figure 1 shows that state 1 of the ergodic distribution has the highest proportion. The proportion in state 2 is also very high. It means that many of the county-level units will migrate to low income states in the future. As the peak of the ergodic distribution is not in state 3 (the interval which contains the mean), it can therefore be concluded that convergence to the mean income is impossible in the long run.

The finding is consistent with those of $\mathrm{Li}$ (2003) and Sakamoto and Islam (2008). Li (2003) showed that the peak in the ergodic distributions is in state 2, which has a range of relative incomes from 0.5 to 0.85 , and hence concluded that it is unlikely for the provinces to converge to the mean income. Using the data from 1952 to 2003, Sakamoto and Islam (2008) found that the income distribution has become bi-modal and that 
the highest peak in the ergodic distribution is in the lowest income state. The congregation of entities at the low end of the ergodic distribution implies that more and more entities will become relatively poorer and the income levels of many entities will be far below the average in the future.

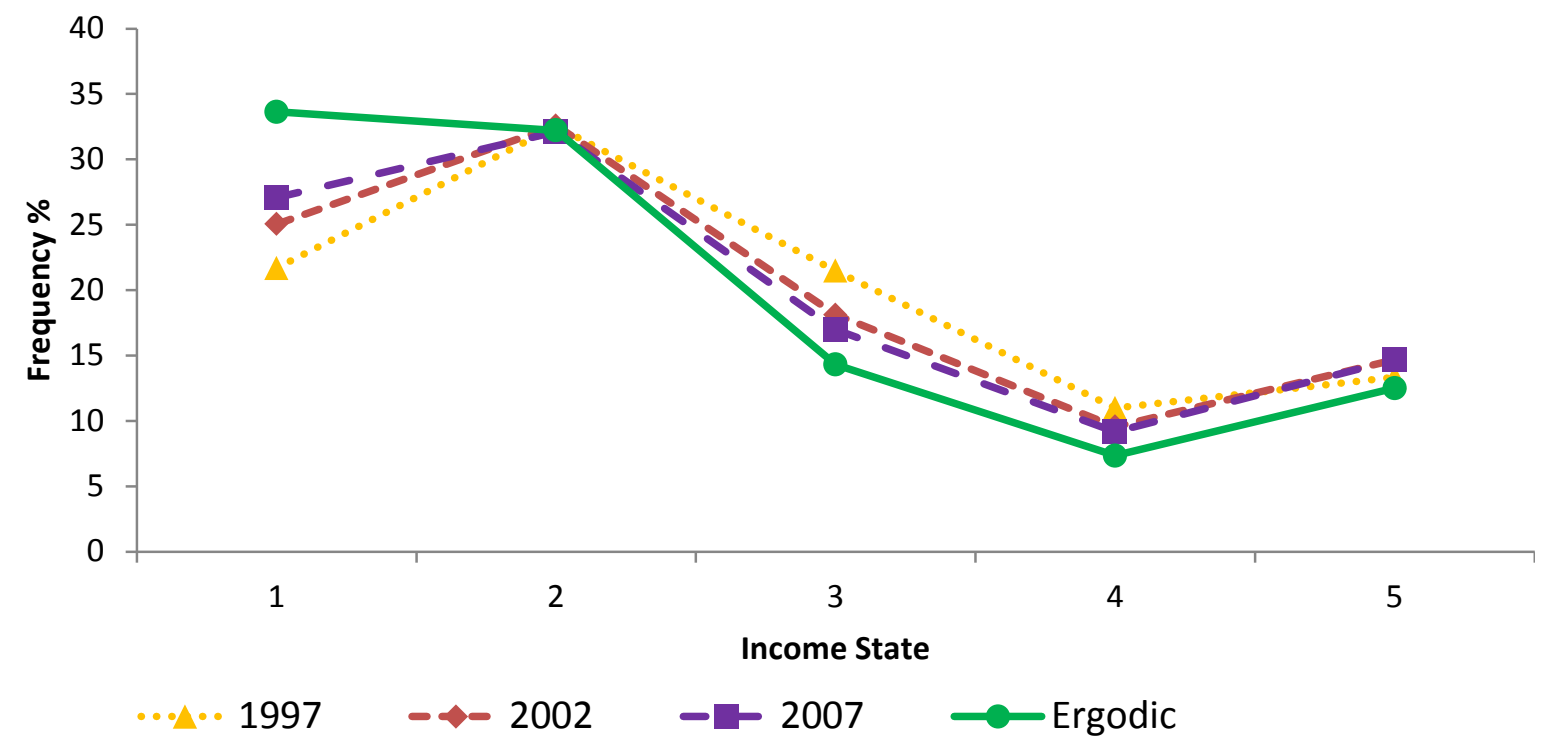

Figure 1 Income Distributions and Ergodic Distribution for the Nation Source: Author's calculation.

Transitional dynamics can be examined by studying the Markov transition matrix in Table 2. The values of the diagonal elements are extremely high, especially at the two ends of the distribution, implying considerable persistence in the income distribution. This finding is consistent with the recent work of Villaverde et al. (2010), who also claim that persistence was very high in China over the period 1978 - 2007. Table 2 also shows that the diagonal elements of state 1 and state 5 are 0.9402 and 0.9449 respectively. This means that the county-level units which belong to the lowest income group and the highest income group have an extremely high probability of remaining in their income states. Although many regions in China have achieved a satisfactory growth rate by international standards, the high probability of staying in state 1 means that the poor cannot migrate to higher income states easily, and tend to remain poor (in a relative sense) in the future.

Table 2 Transition Matrix and Ergodic Distribution for the Nation

\begin{tabular}{crrrrr}
\hline State & 1 & 2 & 3 & 4 & 5 \\
1 & 0.9402 & 0.0587 & 0.0011 & 0.0000 & 0.0000 \\
2 & 0.0621 & 0.8877 & 0.0496 & 0.0002 & 0.0004 \\
3 & 0.0004 & 0.1104 & 0.8209 & 0.0650 & 0.0033 \\
4 & 0.0007 & 0.0081 & 0.1135 & 0.7919 & 0.0858 \\
5 & 0.0000 & 0.0005 & 0.0075 & 0.0472 & 0.9449 \\
Ergodic & $\mathbf{0 . 3 3 6 3}$ & $\mathbf{0 . 3 2 2 2}$ & $\mathbf{0 . 1 4 3 0}$ & $\mathbf{0 . 0 7 3 4}$ & $\mathbf{0 . 1 2 5 1}$ \\
\hline
\end{tabular}

Source: Author's calculation.

Further information on transitional dynamics can be obtained by comparing the probability of moving up and down for states 2, 3 and 4 . The probability value of moving down from state 2 to state 1 is 0.0621 . The 
probability of moving up for state 2 is 0.0502 , which is equal to the sum of the probabilities of moving up from state 2 to states 3,4 and 5 (equal to $0.0496+0.0002+0.0004$ ). The difference between the probabilities of moving down and up can be computed, with the probability of moving down being taken as negative. It is -0.0119 (equal to $0.0502-0.0621$ ) for state 2. This means that entities in state 2 have a higher chance to move down if they move out of state 2 . This comparison can only be carried out for states 2 , 3 , and 4 because it is impossible for the entity to move down beyond state 1 or move up beyond state 5 . The net probability of moving up is -0.0425 for state 3 , while it is -0.0365 for state 4 . The finding is alarming, for it shows that all the entities in states 2,3 , and 4 are likely to move down to lower parts of the income distribution. This together with the observed high persistence in state 1 indicates that the proportion of the lower states of the income distribution will increase over time.

Figure 2 shows the stochastic kernel at the national level over 1997-2007. The density mass is concentrated along the 45-degree diagonal line, implying considerable persistence in the income distribution. This fact can be observed more clearly in Figure 3, which shows the contour plot of the stochastic transition probability kernel of relative incomes in the range $0.2-1.6$. The high concentration of the probability mass along the diagonal line implies that the convergence process will be slow even if it is possible. The findings in Figures 2 and 3 are in agreement with the conclusion derived from the Markov transition matrix shown in Table 2.

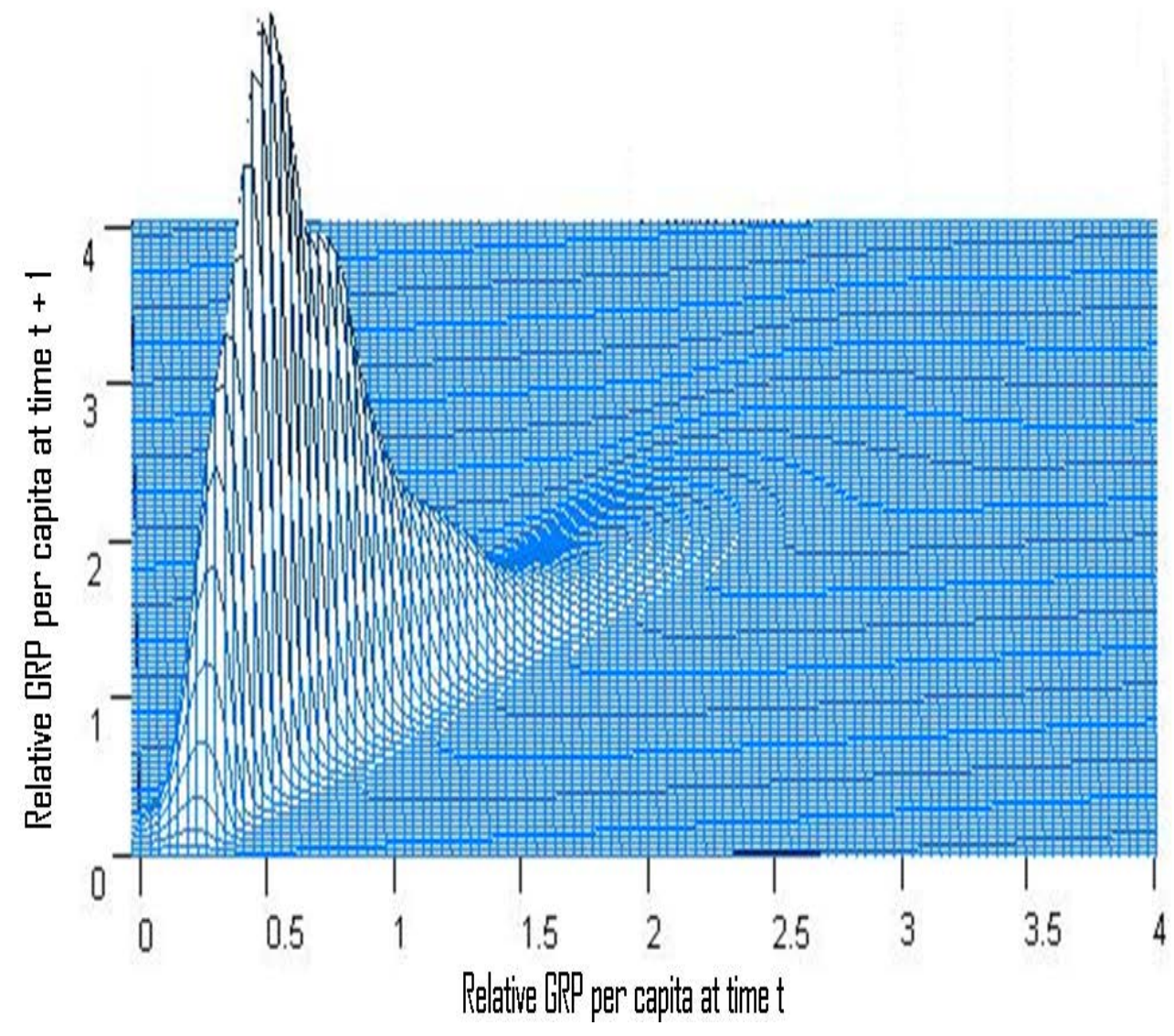

Figure 2 Stochastic Kernel for the Nation Source: Author's calculation. 


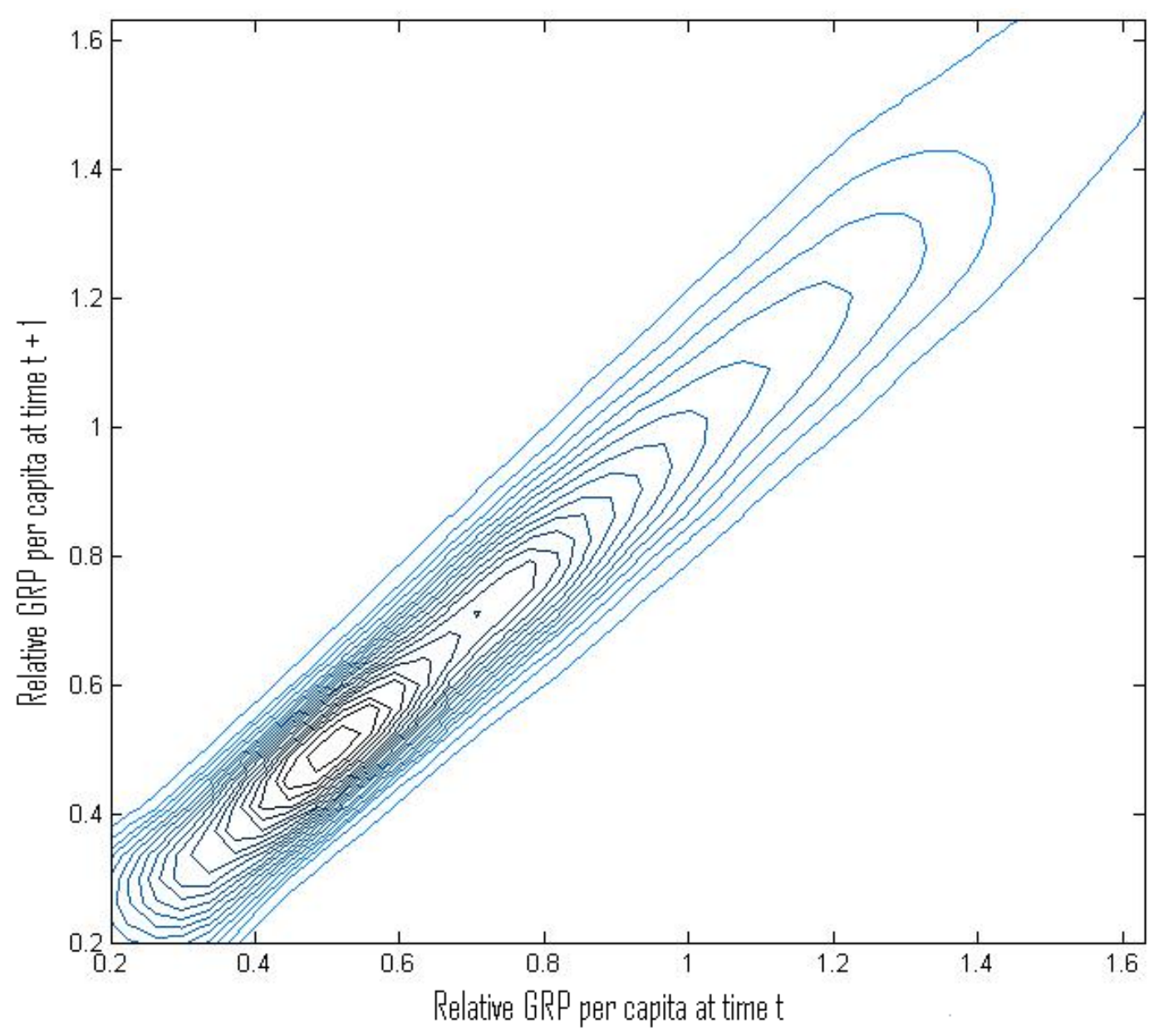

Figure 3 Contour Plot for the Nation Source: Author's calculation.

Figure 4 shows the ergodic distribution computed from the stochastic kernel approach. It provides a forecast into the future and shows that a uni-modal convergence of the income distribution can be achieved in the long run. However, the entities will converge to a value slightly below 0.5 in relative income, which is far below the mean (the value of the mean is 1). This signifies that even though convergence is possible, many entities will congregate around the lower part of the income distribution.

It is of interest to compare the ergodic distribution derived from the Markov transition matrix approach with the one from the stochastic kernel approach. Figure 1, which is based on the Markov transition matrix approach, shows that the peak of the ergodic distribution is in state 1, which is defined as a relative income of 0.5 and below. The proportion in state 1 is about 0.33. Similarly, in Figure 4, the area enclosed under the curve from 0 to 0.5 is about one-third of the overall area underneath the curve. However, Figure 1 shows a small peak in state 5, while Figure 4 does not show any trace of it. This difference can be explained by studying the area under the curve in the long right tail in Figure 4. For the discrete Markov transition matrix approach, state 4 is defined as an interval with relative income from 1.2 to 1.55 , while state 5 includes the entities with their relative income higher than 1.55. Given that the income distribution has a long tail in the upper end as shown in Figure 4, the area enclosed under the curve from 1.55 to the far right end of the 
income distribution is therefore larger than the area under the curve from 1.2 to 1.55 . Thus, both the discrete Markov transition matrix approach and the stochastic kernel approach convey the same message regarding the future evolution of income distribution.

It can be observed that the findings of the stochastic kernel approach are consistent with those of the Markov transition matrix approach in every aspect. The stochastic kernel analysis can be viewed as a test of the robustness of the findings from the Markov transition matrix approach. It shows that the demarcation scheme used in the discrete Markov transition matrix approach is acceptable. Therefore, the same scheme of demarcation is used for all analyses throughout this paper. Hence, subsequent analyses in this paper are based on the Markov transition matrix approach given the fact that mobility can be better studied by using this approach.

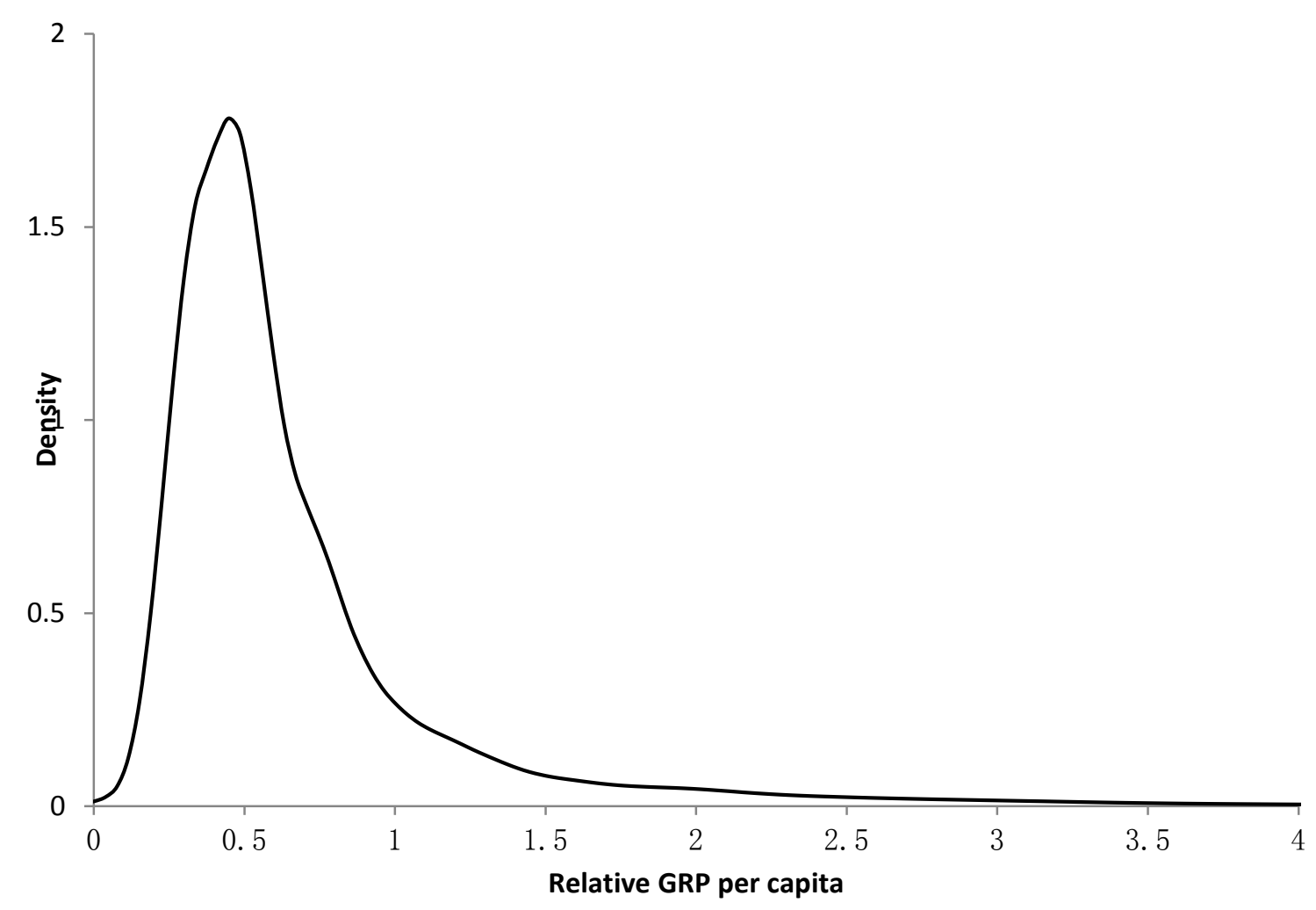

Figure 4 Ergodic Density for the Nation

Source: Author's calculation.

\subsection{Convergence within other spatial groupings}

To provide a comprehensive understanding of the transitional dynamics and convergence patterns, our empirical analysis is conducted within the different spatial groupings. Table 3 shows the Markov transition matrices for different spatial groupings. The values of the diagonal elements are extremely high in every matrix, implying high persistence in all spatial groupings. Moreover, it is observed that the diagonal elements in states 1 and 5 are higher than the other elements in the diagonal in all matrices. Thus the persistence in the lowest and highest income groups is more pronounced than that in the other income groups. 
Convergence analysis is also performed for each province individually. As the number of county-level units in Hainan and Ningxia are small, the Markov transition matrix analysis cannot be applied reliably for these two provinces individually and thus these two provinces are not included in the study. The diagonal elements of the transition matrices of all the provinces are shown in Table 4. In general high persistence is found in all the provinces, except Anhui and Jilin. Strong evidence of persistence can be observed in the lowest income groups in many provinces. In particular, all provinces in the eastern zone show the high probability of remaining in state 1 with Fujian being the highest one with a probability value of 0.9839 . In contrast, the probability values in Anhui and Jilin are the lowest with a value of only 0.5000 .

Table 3 Transition Matrices and Ergodic Distributions for the Regions and Economic Zones

\begin{tabular}{|c|c|c|c|c|c|c|}
\hline & State & 1 & 2 & 3 & 4 & 5 \\
\hline & 1 & 0.9495 & 0.0505 & 0.0000 & 0.0000 & 0.0000 \\
\hline Coastal & 2 & 0.0662 & 0.9059 & 0.0280 & 0.0000 & 0.0000 \\
\hline \multirow{4}{*}{ Region } & 3 & 0.0000 & 0.1034 & 0.8514 & 0.0452 & 0.0000 \\
\hline & 4 & 0.0000 & 0.0000 & 0.0940 & 0.8172 & 0.0888 \\
\hline & 5 & 0.0000 & 0.0000 & 0.0040 & 0.0441 & 0.9519 \\
\hline & Ergodic & 0.4482 & 0.3419 & 0.0925 & 0.0413 & 0.0761 \\
\hline & 1 & 0.9399 & 0.0590 & 0.0005 & 0.0000 & 0.0005 \\
\hline & 2 & 0.0383 & 0.9054 & 0.0546 & 0.0017 & 0.0000 \\
\hline Inland & 3 & 0.0008 & 0.0895 & 0.8382 & 0.0682 & 0.0032 \\
\hline \multirow[t]{3}{*}{ Region } & 4 & 0.0008 & 0.0047 & 0.1455 & 0.7324 & 0.1166 \\
\hline & 5 & 0.0005 & 0.0016 & 0.0075 & 0.0588 & 0.9316 \\
\hline & Ergodic & 0.2169 & 0.3320 & 0.2001 & 0.0887 & 0.1623 \\
\hline \multirow{6}{*}{$\begin{array}{l}\text { Central } \\
\text { Zone }\end{array}$} & 1 & 0.9375 & 0.0625 & 0.0000 & 0.0000 & 0.0000 \\
\hline & 2 & 0.0236 & 0.9242 & 0.0513 & 0.0008 & 0.0000 \\
\hline & 3 & 0.0000 & 0.0776 & 0.8652 & 0.0572 & 0.0000 \\
\hline & 4 & 0.0000 & 0.0056 & 0.1476 & 0.7604 & 0.0864 \\
\hline & 5 & 0.0000 & 0.0026 & 0.0026 & 0.0447 & 0.9500 \\
\hline & Ergodic & 0.1423 & 0.3773 & 0.2423 & 0.0873 & 0.1508 \\
\hline \multirow{6}{*}{$\begin{array}{l}\text { Western } \\
\text { Zone }\end{array}$} & 1 & 0.9459 & 0.0541 & 0.0000 & 0.0000 & 0.0000 \\
\hline & 2 & 0.0420 & 0.8986 & 0.0579 & 0.0005 & 0.0010 \\
\hline & 3 & 0.0000 & 0.1113 & 0.8153 & 0.0719 & 0.0015 \\
\hline & 4 & 0.0000 & 0.0024 & 0.1226 & 0.7767 & 0.0983 \\
\hline & 5 & 0.0000 & 0.0000 & 0.0054 & 0.0612 & 0.9333 \\
\hline & Ergodic & 0.2525 & 0.3254 & 0.1714 & 0.0978 & 0.1529 \\
\hline \multirow{6}{*}{$\begin{array}{l}\text { North-Eastern } \\
\text { Zone }\end{array}$} & 1 & 0.8736 & 0.1154 & 0.0110 & 0.0000 & 0.0000 \\
\hline & 2 & 0.0710 & 0.8664 & 0.0585 & 0.0021 & 0.0021 \\
\hline & 3 & 0.0078 & 0.1016 & 0.8125 & 0.0729 & 0.0052 \\
\hline & 4 & 0.0000 & 0.0054 & 0.1505 & 0.7688 & 0.0753 \\
\hline & 5 & 0.0000 & 0.0063 & 0.0252 & 0.0692 & 0.8994 \\
\hline & Ergodic & 0.2186 & 0.3650 & 0.2205 & 0.1012 & 0.0947 \\
\hline
\end{tabular}

Source: Author's calculation. Note: The coastal region is treated the same as the eastern zone. The inland region includes the central, western, and north-eastern zones. 
Table 4 Probabilities of Staying in State 1 for the Provinces

\begin{tabular}{|c|c|c|c|c|c|c|c|}
\hline Region & Zone & Province & $\begin{array}{l}\text { Prob. of staying in } \\
\text { state } 1\end{array}$ & $\begin{array}{l}\text { Prob. of staying in } \\
\text { state } 2\end{array}$ & $\begin{array}{l}\text { Prob. of staying in } \\
\text { state } 3\end{array}$ & $\begin{array}{l}\text { Prob. of staying in } \\
\text { state } 4\end{array}$ & $\begin{array}{l}\text { Prob. of staying in } \\
\text { state5 }\end{array}$ \\
\hline \multirow{5}{*}{ Coastal } & \multirow{5}{*}{ Eastern } & Fujian & 0.9839 & 0.9593 & 0.8699 & 0.8500 & 0.9556 \\
\hline & & Guangdong & 0.8545 & 0.9470 & 0.8636 & 0.7391 & 0.9318 \\
\hline & & Hebei & 0.9341 & 0.8956 & 0.8364 & 0.8210 & 0.9375 \\
\hline & & Jiangsu & 0.9565 & 0.9272 & 0.9565 & 0.8889 & 0.9889 \\
\hline & & Zhejiang & 0.9322 & 0.9225 & 0.9211 & 0.8615 & 0.8913 \\
\hline \multirow{15}{*}{ Inland } & \multirow{4}{*}{ Central } & Anhui & 0.5000 & 0.8633 & 0.8250 & 0.7841 & 0.9231 \\
\hline & & Henan & 0.7843 & 0.9075 & 0.8439 & 0.8905 & 0.9760 \\
\hline & & Hunan & 0.8596 & 0.9161 & 0.8696 & 0.7891 & 0.9667 \\
\hline & & Jiangxi & 0.8462 & 0.9042 & 0.8301 & 0.8656 & 0.9167 \\
\hline & \multirow{8}{*}{ Western } & Gansu & 0.9010 & 0.9109 & 0.8378 & 0.8088 & 0.9684 \\
\hline & & Guangxi & 0.8043 & 0.8952 & 0.8165 & 0.8219 & 0.8901 \\
\hline & & Guizhou & 0.7333 & 0.9496 & 0.7890 & 0.7416 & 0.9333 \\
\hline & & Inner Mongolia & 0.8889 & 0.8852 & 0.7638 & 0.6900 & 0.9435 \\
\hline & & Qinghai & 0.9091 & 0.8742 & 0.6842 & 0.7222 & 0.8971 \\
\hline & & Sichuan & 0.8115 & 0.9352 & 0.8408 & 0.7624 & 0.9333 \\
\hline & & Xinjiang & 0.9482 & 0.8712 & 0.8316 & 0.7582 & 0.8969 \\
\hline & & Yunnan & 0.9297 & 0.9255 & 0.8864 & 0.8351 & 0.9441 \\
\hline & \multirow{3}{*}{ North-eastern } & Heilongjiang & 0.8500 & 0.8652 & 0.7397 & 0.7833 & 0.9048 \\
\hline & & Jilin & 0.5000 & 0.9396 & 0.8293 & 0.6667 & 0.8919 \\
\hline & & Liaoning & 0.9070 & 0.8454 & 0.8350 & 0.6500 & 0.8519 \\
\hline
\end{tabular}

Source: Author's calculation. Note: The coastal region is treated the same as the eastern zone. The inland region includes the central, western, and north-eastern zones. 
Mobility is shown in Table 5 for different spatial groupings. The table is based on the difference between the sum of probability values of moving up and the sum of probability values of moving down for each state in the transition matrix. It can be observed that most of the probability values in the table are negative, implying that the entities have the higher probability to move down to a lower income group than that to move upwards, although they are more likely to remain in the same states because of the high persistence. The coastal region (that is, the eastern zone) and the north-eastern zone have negative values in all three states. The inland region, the central zone and the western zone have positive value in state 2, but negative values in both states 3 and 4 . Moreover, it can be observed that many of the net probabilities in states 3 and 4 for the provinces are negative. Hebei, Inner Mongolia, and Jiangsu all have negative values in all states. In summary, the transition matrices for the different spatial groupings show that the county-level units will likely remain in the same state, and if they move, they are more likely to move downwards to lower income states.

Table 5 Net Probabilities of Moving Up for Different Spatial Groupings

\begin{tabular}{|c|c|c|c|c|}
\hline & & State 2 & State 3 & State 4 \\
\hline Nation & Nation & -0.0119 & -0.0425 & -0.0365 \\
\hline \multirow{2}{*}{ Region } & Coastal & -0.0382 & -0.0582 & -0.0052 \\
\hline & Inland & 0.0179 & -0.0189 & -0.0344 \\
\hline \multirow{3}{*}{$\begin{array}{l}\text { Economic } \\
\text { Zone }\end{array}$} & Central & 0.0286 & -0.0204 & -0.0669 \\
\hline & Western & 0.0174 & -0.0379 & -0.0267 \\
\hline & North-eastern & -0.0084 & -0.0313 & -0.0806 \\
\hline \multirow{20}{*}{ Province } & Fujian & 0.0111 & -0.0163 & -0.1167 \\
\hline & Guangdong & 0.0303 & 0.0325 & -0.0290 \\
\hline & Hebei & -0.0057 & -0.0833 & -0.0309 \\
\hline & Jiangsu & -0.0464 & -0.0087 & -0.1111 \\
\hline & Zhejiang & -0.0493 & 0.0263 & 0.0308 \\
\hline & Anhui & 0.1079 & -0.0250 & 0.0341 \\
\hline & Henan & -0.0025 & -0.0488 & 0.0073 \\
\hline & Hunan & -0.0070 & 0.0167 & -0.1172 \\
\hline & Jiangxi & 0.0498 & -0.0463 & -0.0699 \\
\hline & Gansu & -0.0486 & 0.0000 & 0.0147 \\
\hline & Guangxi & 0.0699 & 0.0000 & 0.0137 \\
\hline & Guizhou & 0.0216 & -0.1193 & 0.0112 \\
\hline & Inner Mongolia & -0.0333 & -0.0945 & -0.0100 \\
\hline & Qinghai & 0.0000 & -0.1579 & -0.2407 \\
\hline & Sichuan & 0.0000 & -0.0367 & 0.0792 \\
\hline & Xinjiang & 0.0172 & -0.0255 & 0.0440 \\
\hline & Yunnan & 0.0168 & -0.0256 & -0.0206 \\
\hline & Heilongjiang & 0.0043 & 0.0000 & -0.0167 \\
\hline & Jilin & 0.0470 & -0.0081 & -0.2308 \\
\hline & Liaoning & 0.0722 & 0.0097 & -0.0500 \\
\hline
\end{tabular}

Source: Author's calculation. Note: The coastal region is treated the same as the eastern zone. The inland region includes the central, western, and north-eastern zones. The net probability of moving up is calculated as the difference between the sum of probabilities of moving up and the sum of probabilities of moving down, with the probability of moving down being taken as negative in calculation. 


\section{Further Analyses}

It is suggested that transitional dynamics in China are significantly affected by spatial factors. Pu et al. (2005) and He and Zhang (2007) showed that regions have the higher tendency of moving down to low income groups if they are surrounded by poor regions. On the contrary, regions are more likely to move upwards if they are surrounded by rich regions. To explore this issue, The approach of the conditional Markov transition matrix is adopted in this section to evaluate the impact of provincial border on transitional dynamics (Quah (1996b). The conditional Markov transition matrix does not quantify the transitions over time, but it quantifies the conditioning effects. First, the relative incomes of all the entities are calculated based on the mean of the population (that is, the unconditioned relative incomes). Then the entities are divided into subgroups according to the condition. The conditioned relative income for each entity is then calculated based on the mean of the subgroup that the entity belongs to. The conditional Markov transition matrix is then constructed based on the transition from the states of the unconditioned relative incomes to the states of the conditioned relative incomes. The idea is that, if the conditional Markov transition matrix is the same as the identity matrix, it means that the unconditioned relative income states are the same as the conditioned relative income states, thereby implying the transitional dynamics are not related to the condition. On the contrary, if the conditional Markov transition matrix is very different from the identity matrix, it means that the condition accounts for a substantial amount of transitional dynamics.

First of all, the county-level units were grouped into provinces, and the province-conditioned relative income data series were constructed. The Markov transition matrix conditional on the provincial border was estimated by relating the unconditioned relative income data (that is, the relative income data which is based on the national mean) to the province-conditioned relative income data (that is, the relative income data which is based on the mean of each province). Table 6 shows the Markov transition matrix conditional on the provincial border. It can be observed that this matrix is markedly different from the identity matrix. Therefore, it means that provincial border accounts for a considerable amount of the income distribution dynamics. This finding is consistent with those of other researchers (Pu et al., 2005, He and Zhang, 2007). Furthermore, the diagonal value for state 1 is 0.2972 , while the peak of the unconditioned state 1 is 0.6369 which lies in the province-conditioned state 2 . It means that $29.72 \%$ of the poorest entities (relative to the national mean) continue to be the poorest ones as measured by the provincial standard (relative to the provincial mean), while $63.69 \%$ of them are in state 2 as measured by the provincial standard. This suggests that many provinces are very poor and they are mainly made up of very poor county-level units as measured by the national standard. The provincial means of these provinces are lower than the national mean and therefore the county-level units in state 1 (relative to the national mean) move upwards to state 2 (relative to the provincial mean which is much lower than the national mean) within a province. This demonstrates that there is a wide disparity amongst the provinces. 
The possibility of convergence to mean income within a province can also be examined from the province-conditioned state 3 column. If all the elements in this column are close to unity, it does not matter whether the entities are poor or rich (relative to the national mean), they will move to state 3 (relative to the provincial mean) in their respective province, thereby convergence is achieved within each province. However, it can be observed that every element in the province-conditioned state 3 is much smaller than unity, which indicates that it is hard for the entities in a province to converge to the provincial mean. This finding is consistent with those in previous section.

Table 6 Markov Transition Matrix Conditional on Provincial Border

\begin{tabular}{lcrrrrr}
\hline & State & 1 & 2 & 3 & 4 & 5 \\
& 1 & 0.2972 & 0.6369 & 0.0586 & 0.0074 & 0.0000 \\
Unconditioned & 2 & 0.0880 & 0.4536 & 0.3336 & 0.0952 & 0.0296 \\
& 3 & 0.0389 & 0.2709 & 0.3145 & 0.2223 & 0.1534 \\
& 4 & 0.0006 & 0.1751 & 0.3075 & 0.2550 & 0.2618 \\
& 5 & 0.0000 & 0.0254 & 0.1645 & 0.2125 & 0.5975 \\
\hline \multicolumn{7}{c}{ Source: Author's calculation. }
\end{tabular}

Cheng and Li (2006) examine the relative performance of the prefectural level cities and the county-level cities. They find that administrative status has substantial impact on the performance of the cities. Undoubtedly, administrative status plays a major role in future economic development. The impact of the administrative status on the transitional dynamics can be further examined by the conditional Markov transition matrix approach. The mean income of all the cities was calculated first and then the income of each city is divided by this mean to get the status-conditioned relative income data series for the cities. Similarly, the mean income of all the counties was computed and the status-conditioned relative income data series for the counties was constructed by dividing the income of each county by the mean of the counties. The Markov transition matrix conditional on status was then constructed by relating the unconditioned relative income data to the status-conditioned relative income data. The Markov transition matrix conditional on administrative status is shown in Table 7.

Table 7 Markov Transition Matrix Conditional on Administrative Status

\begin{tabular}{rcrrrrr}
\hline & State & 1 & Status-Conditioned & 5 \\
& 1 & 0.5491 & 0.4509 & 0.0000 & 0.0000 & 0.0000 \\
Unconditioned & 2 & 0.0974 & 0.4519 & 0.4506 & 0.0000 & 0.0000 \\
& 3 & 0.0000 & 0.1990 & 0.2120 & 0.5717 & 0.0173 \\
& 4 & 0.0000 & 0.2302 & 0.1120 & 0.0130 & 0.6448 \\
& 5 & 0.0000 & 0.0000 & 0.1751 & 0.1616 & 0.6633 \\
\hline
\end{tabular}

Source: Author's calculation.

It can be observed that the Markov transition matrix conditional on administrative status is significantly different from the identity matrix. This means that conditioning on administrative status accounts for a substantial amount of the inequality dynamic in China. Another observation is that all the elements in the 
status-conditioned state 3 are not close to unity. The highest value is 0.4506 for the unconditioned state 2 . It is $0.0000,0.2120,0.1120,0.1751$ for the unconditioned states $1,3,4$ and 5 respectively. It means that the counties, regardless of the income level (relative to the national mean), are more likely to move away from the mean income state of the counties and to migrate to other states (because the elements in status-conditioned state 3 is very small). Similarly, the cities will also move away from the mean income state of the cities. This corroborates the conclusion in the previous section that shows it is very difficult for the cities to converge to the cities' mean and very difficult for the counties to converge to the counties' mean.

In summary, both conditional Markov transition matrices show that the county-level units within a province cannot converge to the provincial mean. Neither the cities nor the counties can converge to their means. Moreover, the two conditional matrices are very different from the identity matrix. Therefore, it means that provincial border and administrative status account for a considerable amount of the inequality dynamics in China. The results highlight the importance of studying each province individually in convergence analysis. Moreover, the city and county subgroups should also be studied individually.

\section{Conclusions}

This research investigates the issue of convergence within different spatial groupings at various spatial levels, namely, the national, the inland-and-coastal, the economic zonal and the provincial levels. High persistence is found in many Markov transition matrices. It implies that the entities tend to remain in their present income groups. The overall ergodic distribution is also right-skewed for most of the spatial groupings. Convergence to the mean income is virtually impossible in all the provinces (except the province of Liaoning). Furthermore, convergence is found to be impossible for the city subgroups and the county subgroups in different spatial groupings (except the cities in the north-eastern zone). Moreover, it is shown that both spatial factor (provincial border) and the administrative status of county-level units (city and county) play major roles in the transitional dynamics. 
ALONSO, W. 1980. Five Bell Shapes in Development. Papers in Regional Science, 45, 5 - 16.

BARRO, R. J. \& SALA-I-MARTIN, X. 1991. Convergence across States and Regions. Brookings Papers on Economic Activity, 22, 107 - 182.

BARRO, R. J. \& SALA-I-MARTIN, X. 1992. Convergence. Journal of Political Economy, 100, $223-251$.

BERNARD, A. B. \& DURLAUF, S. N. 1995. Convergence in International Output. Journal of Applied Econometrics, 10, 97 - 108.

BERNARD, A. B. \& DURLAUF, S. N. 1996. Interpreting Tests of the Convergence Hypothesis. Journal of Econometrics, 71, 161 - 173.

BICKENBACH, F. \& BODE, E. 2003. Evaluating the Markov Property in Studies of Economic Convergence. International Regional Science Review, 26, 363 - 392.

BISHOP, P. \& GRIPAIOS, P. 2006. Earnings Convergence in UK Counties: A Distribution Dynamics Approach. Applied Economics Letters, 13, 29 - 33.

BOSKER, M. \& KRUGELL, W. 2008. Regional Income evolution in South Africa after Apartheid. Journal of Regional Science, 48, 493 - 523.

CAI, F., WANG, D. \& DU, Y. 2002. Regional Disparity and Economic Growth in China The Impact of Labor Market Distortions. China Economic Review, 13, 197 - 212.

CHANG, G. H. 2002. The Cause and Cure of China's Widening Income Disparity. China Economic Review, 13, 335 - 340.

CHEN, B. \& FENG, Y. 2000. Determinants of Economic Growth in China: Private Enterprise, Education, and Openness. China Economic Review, 11, 1 - 15.

CHEN, J. \& FLEISHER, B. M. 1996. Regional Income Inequality and Economic Growth in China. Journal of Comparative Economics, 22, 141 - 164.

CHEN, Y. P., LIU, M. \& ZHANG, Q. 2010. Development of Financial Intermediation and the Dynamics of Urban-Rural Disparity in China, 1978-1998. Regional Studies 44, 1171 - 1187.

CHENG, Y. S. \& LI, S. K. 2006. A Metafrontier Production Function Analysis of China's City Economies. In: WU, Y. (ed.) Economic Transition, Growth and Globalization in China. Cheltenham, England: Edward Elgar Publishing.

CHEONG, T. S. 2012. Trends, Determinants and Consequences of Regional Inequality in China: New Evidence. Doctoral dissertation, University of Western Australia.

CHOI, H. \& LI, H. 2000. Economic Development and Growth Convergence in China. Journal of International Trade \& Economic Development, 9, 37 - 54.

DACOSTA, M. \& CARROLL, W. 2001. Township and Village Enterprises, Openness and Regional Economic Growth in China. Post-Communist Economies, 13, 229 - 241.

DUAN, P. 2008. Influence of China's Population Mobility on the Change of Regional Disparity since 1978 China Population, 18, 27 - 33.

EPSTEIN, P., HOWLETT, P. \& SCHULZE, M.-S. 2003. Distribution Dynamics: Stratification, Polarization, and Convergence among OECD Economies, 1870-1992. Explorations in Economic History, 40, 78 - 97.

FAN, C. C. 1995. Of Belts and Ladders: State Policy and Uneven Regional Development in Post-Mao China. Annals of the Association of American Geographers, 85, 421 - 449.

FINGLETON, B. 1999. Estimates of Time to Economic Convergence: An Analysis of Regions of the European Union. International Regional Science Review, 22, 5 - 34.

FUJITA, M., KRUGMAN, P. \& VENABLES, A. J. 1999. The Spatial Economy: Cities, Regions, and International Trade. Cambridge, MA: MIT Press.

GALLO, J. L. 2004. Space-Time Analysis of GDP Disparities among European Regions: A Markov Chains Approach. International Regional Science Review, 27, 138 - 163. 
GEPPERT, K. \& STEPHAN, A. 2008. Regional Disparities in the European Union: Convergence and Agglomeration. Papers in Regional Science, 87, 193 - 217.

GOH, C.-C., LUO, X. \& ZHU, N. 2009. Income Growth, Inequality and Poverty Reduction: A Case Study of Eight Provinces in China. China Economic Review, 20, 485 - 496.

GRIES, T. \& REDLIN, M. 2011. International Integration and the Determinants of Regional Development in China Economic Change and Restructuring, 44, 149 - 177.

GUNDLACH, E. 1997. Regional Convergence of Output per Worker in China: A Neoclassical Interpretation. Asian Economic Journal, 11, 423 - 442.

HAO, R. 2008. Opening up, Market Reform, and Convergence Clubs in China. Asian Economic Journal, 22, 133 - 160.

HE, J. \& ZHANG, X. 2007. Spatial-Temporal Analysis of China's Regional Income Distribution Dynamics. South China Journal of Economics (in Chinese).

HERTEL, T. \& ZHAI, F. 2006. Labor Market Distortions, Rural-Urban Inequality and the Opening of China's Economy. Economic Modelling, 23, 76 - 109.

HIGGINS, M. J., LEVY, D. \& YOUNG, A. T. 2006. Growth and Convergence Across the United States Evidence from County-Level Data. The Review of Economics and Statistics, 88, 671 681.

HOBIJN, B. \& FRANSES, P. H. 2000. Asymptotically Perfect and Relative Convergence of Productivity. Journal of Applied Econometrics, 15, 59 - 81.

JIAN, T., SACHS, J. D. \& WARNER, A. M. 1996. Trends in Regional Inequality in China. China Economic Review, 7, 1 - 21.

JOHNSON, P. A. 2000. A Nonparametric Analysis of Income Convergence across the US States. Economics Letters, 69, 219 - 223.

JOHNSON, P. A. 2005. A Continuous State Space Approach to "Convergence by Parts". Economics Letters, 86, 317 - 321.

JONES, C. I. 1997. On the Evolution of the World Income Distribution. Journal of Economic Perspectives, 11, 19 - 36.

JUESSEN, F. 2009. A Distribution Dynamics Approach to Regional GDP Convergence in Unified Germany. Empirical Economics, 37, 627 - 652.

KANBUR, R. \& ZHANG, X. 1999. Which Regional Inequality? The Evolution of Rural-Urban and Inland-Coastal Inequality in China from 1983 to 1995. Journal of Comparative Economics, 27, 686 - 701.

KANBUR, R. \& ZHANG, X. 2005. Fifty Years of Regional Inequality in China: a Journey Through Central Planning, Reform, and Openness. Review of Development Economics, 9, 87 - 106.

KEMENY, J. G. \& SNELL, J. L. 1976. Finite Markov Chains, New York, Springer.

KRUGMAN, P. 1991a. Geography and Trade, Cambridge, MA, MIT Press.

KRUGMAN, P. 1991b. Increasing Returns and Economic Geography. Journal of Political Economy, 99, 483 - 499.

KRUGMAN, P. \& VENABLES, A. J. 1995. Globalization and the Inequality of Nations. NBER working paper series, 5098.

KUZNETS, S. 1955. Economic Growth and Income Inequality. American Economic Review, 45, 1 28.

LAU, C. K. M. 2010. New Evidence About Regional Income Divergence in China. China Economic Review, 21, 293 - 309.

LE GALLO, J. 2004. Space-Time Analysis of GDP Disparities among European Regions: Markov Chains Approach. International Regional Science Review, 27, 138 - 163.

LEE, J. 2000. Changes in the Source of China's Regional Inequality. China Economic Review, 11, $232-245$.

LI, G., ZENG, X. \& ZHANG, L. 2008. Study of Agricultural Productivity and Its Convergence across China's Regions. Review of Regional Studies, 38, 361 - 379. 
LI, H. 2003. Dynamics of Income Distribution across Chinese Provinces during 1978-98. Journal of Chinese Economic and Business Studies, 1, 145 - 157.

LI, S. \& XU, Z. 2008. The Trend of Regional Income Disparity in the People's Republic of China. ADBI Discussion Paper 85. Tokyo: Asian Development Bank Institute.

LIM, L. K. \& MCALEER, M. 2004. Convergence and Catching Up in ASEAN: A Comparative Analysis. Applied Economics, 36, 137 - 153.

LIN, T., ZHUANG, J., YARCIA, D. \& LIN, F. 2008. Income Inequality in the People's Republic of China and Its Decomposition: 1990-2004. Asian Development Review, 25, 119 - 136.

LIU, H. \& WANG, L. 2010. Time Series Analysis of Income Convergence in China. Applied Economics Letters, 17, 25 - 29.

LIU, X. 2010. Decomposition of China's Income Inequality, 1995-2006. Chinese Economy, 43, 49 72.

LU, D. 2002. Rural-Urban Income Disparity: Impact of Growth, Allocative Efficiency, and Local Growth Welfare. China Economic Review, 13, 419 - 429.

LU, M. \& CHEN, Z. 2006. Urbanization, Urban-Biased Policies, and Urban-Rural Inequality in China, 1987 - 2001. The Chinese Economy, 39, 42 - 63.

LU, M. \& WANG, E. 2002. Forging Ahead and Falling Behind: Changing Regional Inequalities in Post-Reform China. Growth and Change, 33, 42 - 71.

LUCAS, R. E. 1988. On the Mechanics of Economic Development. Journal of Monetary Economics, 22, 3 - 42.

LYONS, T. P. 1991. Interprovincial Disparities in China: Output and Consumption, 1952 - 1987. Economic Development and Cultural Change, 39, 471 - 506.

MAGRINI, S. 1999. The Evolution of Income Disparities among the Regions of the European Union. Regional Science and Urban Economics, 29, 257 - 281.

MARTI, L., PUERTAS, R. \& FERNANDEZ, J. I. 2011. Industrial Productivity and Convergence in Chinese Regions: The Effects of Entering the World Trade Organisation. Journal of Asian Economics 22, 128 - 141.

MATSUKI, T. \& USAMI, R. 2011. China's Regional Convergence in Panels with Multiple Structural Breaks. Applied Economics, 43, 873 - 890.

OXLEY, L. \& GREASLEY, D. 1995. A Time-Series Perspective on Convergence: Australia, UK and USA since 1870. Economic Record, 71, 259 - 270.

PEDRONI, P. \& YAO, J. Y. 2006. Regional Income Divergence in China. Journal of Asian Economics, 17, 294 - 315.

PESARAN, M. H. 2007. A Pair-Wise Approach to Testing for Output and Growth Convergence. Journal of Econometrics, 138, 312 - 355.

PU, Y.-X., MA, R.-H., GE, Y. \& HUANG, X.-Y. 2005. Spatial-Temporal Dynamics of Regional Convergence at County Level in Jiangsu. Chinese Geographical Science, 15.

QUAH, D. 1993. Empirical Cross-Section Dynamics in Economic Growth. European Economic Review, 37, 426 - 434.

QUAH, D. 2001. Searching for Prosperity: A Comment Carnegie-Rochester Conference Series on Public Policy, 55, 305 - 319.

QUAH, D. T. 1996a. Empirics for Economic Growth and Convergence. European Economic Review, 40, $1353-1375$.

QUAH, D. T. 1996b. Regional Convergence Clusters across Europe. European Economic Review, 40, $951-958$.

QUAH, D. T. 1996c. Twin Peaks: Growth and Convergence in Models of Distribution Dynamics. The Economic Journal, 106, 1045 - 1055.

RAISER, M. 1998. Subsidising Inequality: Economic Reforms, Fiscal Transfers and Convergence across Chinese Provinces. The Journal of Development Studies, 34, 1 - 26. 
REY, S. J. 2001. Spatial Empirics for Economic Growh and Convergence. Geographical Analysis, 33, 195 - 214.

ROMER, P. M. 1986. Increasing Returns and Long-run Growth. Journal of Political Economy, 94, 1002 - 1037.

SAKAMOTO, H. 2007. The Dynamics of Inter-Provincial Income Distribution in Indonesia. Working Paper Series, 2007.

SAKAMOTO, H. \& FAN, J. 2010. Distribution Dynamics and Convergence among 75 Cities and Counties in Yangtze River Delta in China: 1990-2005. Review of Urban and Regional Development Studies, 22, 39 - 54.

SAKAMOTO, H. \& ISLAM, N. 2008. Convergence across Chinese Provinces: An analysis Using Markov Transition Matrix. China Economic Review, 19, 66 - 79.

SHEN, L. 2009. The Urban-Rural Disparity: A Demand Side Analysis. Journal of Developing Areas 43, 87 - 107.

SICULAR, T., YUE, X., GUSTAFSSON, B. \& LI, S. 2007. The Urban-Rural Income Gap and Inequality in China. Review of Income and Wealth, 53, 93 - 126.

SILVERMAN, B. W. 1986. Density Estimation for Statistics and Data Analysis, New York, Chapman and Hall.

SOLOW, R. M. 1956. A Contribution to the Theory of Economic Growth. The Quarterly Journal of Economics, 70, 65 - 94.

STATE STATISTICAL BUREAU 1998 - 2008a. Provincial Statistical Yearbook, Beijing, China Statistics Press.

STATE STATISTICAL BUREAU 1998 - 2008b. Provincial Yearbook, Beijing, China Statistics Press.

STATE STATISTICAL BUREAU 2004 - 2008. China Statistical Yearbook for Regional Economy, Beijing, China Statistics Press.

STATE STATISTICAL BUREAU 2006. China Statistical Yearbook, Beijing, China Statistics Press.

SUTHERLAND, D. \& YAO, S. 2011. Income Inequality in China over 30 Years of Reforms. Cambridge Journal of Regions, Economy and Society, 4, 91 - 105.

SWAN, T. W. 1956. Economic Growth and Capital Accumulation. Economic Record, 32, 334 - 361.

TIAN, X. 1999. Market Orientation and Regional Disparities in China. Post-Communist Economies, 11, 161 - 172.

TSUI, K.-Y. 1993. Decomposition of China's Regional Inequalities. Journal of Comparative Economics, 17, 600 - 627.

TSUI, K.-Y. 1996. Economic Reform and Interprovincial Inequality in China. Journal of Development Economics, 50, 353 - 368.

VILLAVERDE, J., MAZA, A. \& RAMASAMY, B. 2010. Provincial Disparities in Post-reform China. China and World Economy, 18, 73 - 95.

WEEKS, M. \& YAO, J. Y. 2003. Provincial Conditional Income Convergence in China, 1953-1997: A Panel Data Approach. Econometric Reviews, 22, 59 - 77.

WESTERLUND, J., EDGERTON, D. L. \& OPPER, S. 2010. Why is Chinese Provincial Output Diverging? . Journal of Asian Economics, 21, 333 - 344.

WHALLEY, J. \& YUE, X. 2009. Rural Income Volatility and Inequality in China. CESifo Economic Studies, 55, 648 - 668.

WILLIAMSON, J. G. 1965. Regional Inequality and the Process of National Development: A Description of the Patterns. Economic Development and Cultural Change, 13, 1 - 84.

WU, X. \& PERLOFF, J. M. 2005. China's Income Distribution, 1985-2001. Review of Economics and Statistics, 87, $763-775$.

WU, Y. 2004. China's Economic Growth: A Miracle with Chinese Characteristics, London \& New York, Routledge Curzon Press. 
YANG, D. T. 1999. Urban-Biased Policies and Rising Income Inequality in China. The American Economic Review, 89, 306 - 310.

YAO, S. \& ZHANG, Z. 2001a. On Regional Inequality and Diverging Clubs: A Case Study of Contemporary China. Journal of Comparative Economics, 29, 466 - 484.

YAO, S. \& ZHANG, Z. 2001b. Regional Growth in China Under Economic Reforms. The Journal of Development Studies, 38, 167 - 186.

YAO, S. \& ZHANG, Z. 2002. Economic Growth and Diverging Clubs: a Case Study of the Chinese Regions. Applied Economics Letters, 9, 833 - 836.

YAO, S., ZHANG, Z. \& FENG, G. 2005. Rural-Urban and Regional Inequality in Output, Income and Consumption in China under Economic Reforms. Journal of Economic Studies, 32, 4 24.

ZHANG, Z., LIU, A. \& YAO, S. 2001. Convergence of China's Regional Incomes 1952 - 1997. China Economic Review, 12, 243 - 258.

ZHENG, F., XU, L. D. \& TANG, B. 2000. Forecasting Regional Income Inequality in China. European Journal of Operational Research, 124, 243 - 254.

ZHOU, H. \& ZOU, W. 2010. Income Distribution Dynamics of Urban Residents: The case of China (1995-2004). Frontiers of Economics in China, 5, 114 - 134.

ZHUANG, J. 2008. Inclusive Growth toward a Harmonious Society in the People's Republic of China: Policy Implications. Asian Development Review, 25, 22 - 33.

ZOU, W., ZHUANG, Z., ZHOU, H. \& SONG, H. 2008. Measuring Divergence in Provincial Growth in China: 1981-2004. Journal of Economic Policy Reform, 11, 215 - 227. 


\section{ECONOMICS DISCUSSION PAPERS}

2010

\begin{tabular}{|c|c|c|}
\hline $\begin{array}{l}\text { DP } \\
\text { NUMBER }\end{array}$ & AUTHORS & TITLE \\
\hline 10.01 & Hendry, D.F. & $\begin{array}{l}\text { RESEARCH AND THE ACADEMIC: A TALE OF } \\
\text { TWO CULTURES }\end{array}$ \\
\hline 10.02 & McLure, M., Turkington, D. and Weber, E.J. & A CONVERSATION WITH ARNOLD ZELLNER \\
\hline 10.03 & $\begin{array}{l}\text { Butler, D.J., Burbank, V.K. and } \\
\text { Chisholm, J.S. }\end{array}$ & $\begin{array}{l}\text { THE FRAMES BEHIND THE GAMES: PLAYER'S } \\
\text { PERCEPTIONS OF PRISONER'S DILEMMA, } \\
\text { CHICKEN, DICTATOR, AND ULTIMATUM GAMES }\end{array}$ \\
\hline 10.04 & Harris, R.G., Robertson, P.E. and Xu, J.Y. & $\begin{array}{l}\text { THE INTERNATIONAL EFFECTS OF CHINA'S } \\
\text { GROWTH, TRADE AND EDUCATION BOOMS }\end{array}$ \\
\hline 10.05 & Clements, K.W., Mongey, S. and Si, J. & $\begin{array}{l}\text { THE DYNAMICS OF NEW RESOURCE PROJECTS A } \\
\text { PROGRESS REPORT }\end{array}$ \\
\hline 10.06 & Costello, G., Fraser, P. and Groenewold, N. & $\begin{array}{l}\text { HOUSE PRICES, NON-FUNDAMENTAL } \\
\text { COMPONENTS AND INTERSTATE SPILLOVERS: } \\
\text { THE AUSTRALIAN EXPERIENCE }\end{array}$ \\
\hline 10.07 & Clements, K. & $\begin{array}{l}\text { REPORT OF THE } 2009 \text { PHD CONFERENCE IN } \\
\text { ECONOMICS AND BUSINESS }\end{array}$ \\
\hline 10.08 & Robertson, P.E. & $\begin{array}{l}\text { INVESTMENT LED GROWTH IN INDIA: HINDU } \\
\text { FACT OR MYTHOLOGY? }\end{array}$ \\
\hline 10.09 & Fu, D., Wu, Y. and Tang, Y. & $\begin{array}{l}\text { THE EFFECTS OF OWNERSHIP STRUCTURE AND } \\
\text { INDUSTRY CHARACTERISTICS ON EXPORT } \\
\text { PERFORMANCE }\end{array}$ \\
\hline 10.10 & Wu, Y. & $\begin{array}{l}\text { INNOVATION AND ECONOMIC GROWTH IN } \\
\text { CHINA }\end{array}$ \\
\hline 10.11 & Stephens, B.J. & $\begin{array}{l}\text { THE DETERMINANTS OF LABOUR FORCE } \\
\text { STATUS AMONG INDIGENOUS AUSTRALIANS }\end{array}$ \\
\hline 10.12 & Davies, $\mathrm{M}$. & $\begin{array}{l}\text { FINANCING THE BURRA BURRA MINES, SOUTH } \\
\text { AUSTRALIA: LIQUIDITY PROBLEMS AND } \\
\text { RESOLUTIONS }\end{array}$ \\
\hline 10.13 & Tyers, R. and Zhang, Y. & APPRECIATING THE RENMINBI \\
\hline 10.14 & Clements, K.W., Lan, Y. and Seah, S.P. & $\begin{array}{l}\text { THE BIG MAC INDEX TWO DECADES ON } \\
\text { AN EVALUATION OF BURGERNOMICS }\end{array}$ \\
\hline 10.15 & Robertson, P.E. and Xu, J.Y. & $\begin{array}{l}\text { IN CHINA'S WAKE: } \\
\text { HAS ASIA GAINED FROM CHINA'S GROWTH? }\end{array}$ \\
\hline 10.16 & Clements, K.W. and Izan, H.Y. & $\begin{array}{l}\text { THE PAY PARITY MATRIX: A TOOL FOR } \\
\text { ANALYSING THE STRUCTURE OF PAY }\end{array}$ \\
\hline 10.17 & Gao, G. & WORLD FOOD DEMAND \\
\hline 10.18 & Wu, Y. & $\begin{array}{l}\text { INDIGENOUS INNOVATION IN CHINA: } \\
\text { IMPLICATIONS FOR SUSTAINABLE GROWTH }\end{array}$ \\
\hline 10.19 & Robertson, P.E. & DECIPHERING THE HINDU GROWTH EPIC \\
\hline 10.20 & Stevens, G. & $\begin{array}{l}\text { RESERVE BANK OF AUSTRALIA-THE ROLE OF } \\
\text { FINANCE }\end{array}$ \\
\hline 10.21 & Widmer, P.K., Zweifel, P. and Farsi, M. & $\begin{array}{l}\text { ACCOUNTING FOR HETEROGENEITY IN THE } \\
\text { MEASUREMENT OF HOSPITAL PERFORMANCE }\end{array}$ \\
\hline
\end{tabular}




\begin{tabular}{|l|l|l|}
\hline 10.22 & McLure, M. & $\begin{array}{l}\text { ASSESSMENTS OF A. C. PIGOU'S FELLOWSHIP } \\
\text { THESES }\end{array}$ \\
\hline 10.23 & Poon, A.R. & $\begin{array}{l}\text { THE ECONOMICS OF NONLINEAR PRICING: } \\
\text { EVIDENCE FROM AIRFARES AND GROCERY } \\
\text { PRICES }\end{array}$ \\
\hline 10.24 & Halperin, D. & $\begin{array}{l}\text { FORECASTING METALS RETURNS: A BAYESIAN } \\
\text { DECISION THEORETIC APPROACH }\end{array}$ \\
\hline 10.25 & Clements, K.W. and Si. J. & $\begin{array}{l}\text { THE INVESTMENT PROJECT PIPELINE: COST } \\
\text { ESCALATION, LEAD-TIME, SUCCESS, FAILURE } \\
\text { AND SPEED }\end{array}$ \\
\hline 10.26 & Chen, A., Groenewold, N. and Hagger, A.J. & $\begin{array}{l}\text { THE REGIONAL ECONOMIC EFFECTS OF A } \\
\text { REDUCTION IN CARBON EMISSIONS }\end{array}$ \\
\hline 10.27 & $\begin{array}{l}\text { Siddique, A., Selvanathan, E.A. and } \\
\text { Selvanathan, S. }\end{array}$ & $\begin{array}{l}\text { REMITTANCES AND ECONOMIC GROWTH: } \\
\text { EMPIRICAL EVIDENCE FROM BANGLADESH, } \\
\text { INDIA AND SRI LANKA }\end{array}$ \\
\hline
\end{tabular}


ECONOMICS DISCUSSION PAPERS

2011

\begin{tabular}{|c|c|c|}
\hline $\begin{array}{l}\text { DP } \\
\text { NUMBER }\end{array}$ & AUTHORS & TITLE \\
\hline 11.01 & Robertson, P.E. & DEEP IMPACT: CHINA AND THE WORLD ECONOMY \\
\hline 11.02 & Kang, C. and Lee, S.H. & $\begin{array}{l}\text { BEING KNOWLEDGEABLE OR SOCIABLE? } \\
\text { DIFFERENCES IN RELATIVE IMPORTANCE OF } \\
\text { COGNITIVE AND NON-COGNITIVE SKILLS }\end{array}$ \\
\hline 11.03 & Turkington, D. & DIFFERENT CONCEPTS OF MATRIX CALCULUS \\
\hline 11.04 & Golley, J. and Tyers, R. & $\begin{array}{l}\text { CONTRASTING GIANTS: DEMOGRAPHIC CHANGE } \\
\text { AND ECONOMIC PERFORMANCE IN CHINA AND } \\
\text { INDIA }\end{array}$ \\
\hline 11.05 & Collins, J., Baer, B. and Weber, E.J. & $\begin{array}{l}\text { ECONOMIC GROWTH AND EVOLUTION: } \\
\text { PARENTAL PREFERENCE FOR QUALITY AND } \\
\text { QUANTITY OF OFFSPRING }\end{array}$ \\
\hline 11.06 & Turkington, D. & $\begin{array}{l}\text { ON THE DIFFERENTIATION OF THE LOG } \\
\text { LIKELIHOOD FUNCTION USING MATRIX } \\
\text { CALCULUS }\end{array}$ \\
\hline 11.07 & Groenewold, N. and Paterson, J.E.H. & $\begin{array}{l}\text { STOCK PRICES AND EXCHANGE RATES IN } \\
\text { AUSTRALIA: ARE COMMODITY PRICES THE } \\
\text { MISSING LINK? }\end{array}$ \\
\hline 11.08 & Chen, A. and Groenewold, N. & $\begin{array}{l}\text { REDUCING REGIONAL DISPARITIES IN CHINA: IS } \\
\text { INVESTMENT ALLOCATION POLICY EFFECTIVE? }\end{array}$ \\
\hline 11.09 & Williams, A., Birch, E. and Hancock, P. & $\begin{array}{l}\text { THE IMPACT OF ON-LINE LECTURE RECORDINGS } \\
\text { ON STUDENT PERFORMANCE }\end{array}$ \\
\hline 11.10 & Pawley, J. and Weber, E.J. & $\begin{array}{l}\text { INVESTMENT AND TECHNICAL PROGRESS IN THE } \\
\text { G7 COUNTRIES AND AUSTRALIA }\end{array}$ \\
\hline 11.11 & Tyers, R. & $\begin{array}{l}\text { AN ELEMENTAL MACROECONOMIC MODEL FOR } \\
\text { APPLIED ANALYSIS AT UNDERGRADUATE LEVEL }\end{array}$ \\
\hline 11.12 & Clements, K.W. and Gao, G. & QUALITY, QUANTITY, SPENDING AND PRICES \\
\hline 11.13 & Tyers, R. and Zhang, Y. & $\begin{array}{l}\text { JAPAN'S ECONOMIC RECOVERY: INSIGHTS FROM } \\
\text { MULTI-REGION DYNAMICS }\end{array}$ \\
\hline 11.14 & McLure, M. & A. C. PIGOU'S REJECTION OF PARETO’S LAW \\
\hline 11.15 & Kristoffersen, I. & $\begin{array}{l}\text { THE SUBJECTIVE WELLBEING SCALE: HOW } \\
\text { REASONABLE IS THE CARDINALITY } \\
\text { ASSUMPTION? }\end{array}$ \\
\hline 11.16 & Clements, K.W., Izan, H.Y. and Lan, Y. & VOLATILITY AND STOCK PRICE INDEXES \\
\hline 11.17 & Parkinson, $\mathrm{M}$. & $\begin{array}{l}\text { SHANN MEMORIAL LECTURE 2011: SUSTAINABLE } \\
\text { WELLBEING - AN ECONOMIC FUTURE FOR } \\
\text { AUSTRALIA }\end{array}$ \\
\hline 11.18 & Chen, A. and Groenewold, N. & $\begin{array}{l}\text { THE NATIONAL AND REGIONAL EFFECTS OF } \\
\text { FISCAL DECENTRALISATION IN CHINA }\end{array}$ \\
\hline 11.19 & Tyers, R. and Corbett, J. & $\begin{array}{l}\text { JAPAN'S ECONOMIC SLOWDOWN AND ITS } \\
\text { GLOBAL IMPLICATIONS: A REVIEW OF THE } \\
\text { ECONOMIC MODELLING }\end{array}$ \\
\hline 11.20 & Wu, Y. & $\begin{array}{l}\text { GAS MARKET INTEGRATION: GLOBAL TRENDS } \\
\text { AND IMPLICATIONS FOR THE EAS REGION }\end{array}$ \\
\hline
\end{tabular}




\begin{tabular}{|l|l|l|}
\hline 11.21 & Fu, D., Wu, Y. and Tang, Y. & $\begin{array}{l}\text { DOES INNOVATION MATTER FOR CHINESE } \\
\text { HIGH-TECH EXPORTS? A FIRM-LEVEL ANALYSIS }\end{array}$ \\
\hline 11.22 & Fu, D. and Wu, Y. & $\begin{array}{l}\text { EXPORT WAGE PREMIUM IN CHINA'S } \\
\text { MANUFACTURING SECTOR: A FIRM LEVEL } \\
\text { ANALYSIS }\end{array}$ \\
\hline 11.23 & Li, B. and Zhang, J. & $\begin{array}{l}\text { SUBSIDIES IN AN ECONOMY WITH ENDOGENOUS } \\
\text { CYCLES OVER NEOCLASSICAL INVESTMENT AND } \\
\text { NEO-SCHUMPETERIAN INNOVATION REGIMES }\end{array}$ \\
\hline 11.24 & Krey, B., Widmer, P.K. and Zweifel, P. & $\begin{array}{l}\text { EFFICIENT PROVISION OF ELECTRICITY FOR THE } \\
\text { UNITED STATES AND SWITZERLAND }\end{array}$ \\
\hline 11.25 & Wu, Y. & $\begin{array}{l}\text { ENERGY INTENSITY AND ITS DETERMINANTS IN } \\
\text { CHINA'S REGIONAL ECONOMIES }\end{array}$ \\
\hline & & \\
\hline
\end{tabular}




\begin{tabular}{|c|c|c|}
\hline \multicolumn{3}{|c|}{$\begin{array}{l}\text { ECONOMICS DISCUSSION PAPERS } \\
2012\end{array}$} \\
\hline $\begin{array}{l}\text { DP } \\
\text { NUMBER }\end{array}$ & AUTHORS & TITLE \\
\hline 12.01 & $\begin{array}{l}\text { Clements, K.W., Gao, G., and } \\
\text { Simpson, T. }\end{array}$ & $\begin{array}{l}\text { DISPARITIES IN INCOMES AND PRICES } \\
\text { INTERNATIONALLY }\end{array}$ \\
\hline 12.02 & Tyers, R. & $\begin{array}{l}\text { THE RISE AND ROBUSTNESS OF ECONOMIC FREEDOM } \\
\text { IN CHINA }\end{array}$ \\
\hline 12.03 & Golley, J. and Tyers, R. & $\begin{array}{l}\text { DEMOGRAPHIC DIVIDENDS, DEPENDENCIES AND } \\
\text { ECONOMIC GROWTH IN CHINA AND INDIA }\end{array}$ \\
\hline 12.04 & Tyers, R. & LOOKING INWARD FOR GROWTH \\
\hline 12.05 & Knight, K. and McLure, M. & THE ELUSIVE ARTHUR PIGOU \\
\hline 12.06 & McLure, M. & $\begin{array}{l}\text { ONE HUNDRED YEARS FROM TODAY: A. C. PIGOU'S } \\
\text { WEALTH AND WELFARE }\end{array}$ \\
\hline 12.07 & Khuu, A. and Weber, E.J. & HOW AUSTRALIAN FARMERS DEAL WITH RISK \\
\hline 12.08 & Chen, M. and Clements, K.W. & PATTERNS IN WORLD METALS PRICES \\
\hline 12.09 & Clements, K.W. & UWA ECONOMICS HONOURS \\
\hline 12.10 & Golley, J. and Tyers, R. & $\begin{array}{l}\text { CHINA'S GENDER IMBALANCE AND ITS ECONOMIC } \\
\text { PERFORMANCE }\end{array}$ \\
\hline 12.11 & Weber, E.J. & $\begin{array}{l}\text { AUSTRALIAN FISCAL POLICY IN THE AFTERMATH OF } \\
\text { THE GLOBAL FINANCIAL CRISIS }\end{array}$ \\
\hline 12.12 & Hartley, P.R. and Medlock III, K.B. & $\begin{array}{l}\text { CHANGES IN THE OPERATIONAL EFFICIENCY OF } \\
\text { NATIONAL OIL COMPANIES }\end{array}$ \\
\hline 12.13 & Li, L. & $\begin{array}{l}\text { HOW MUCH ARE RESOURCE PROJECTS WORTH? A } \\
\text { CAPITAL MARKET PERSPECTIVE }\end{array}$ \\
\hline 12.14 & Chen, A. and Groenewold, N. & $\begin{array}{l}\text { THE REGIONAL ECONOMIC EFFECTS OF A REDUCTION } \\
\text { IN CARBON EMISSIONS AND AN EVALUATION OF } \\
\text { OFFSETTING POLICIES IN CHINA }\end{array}$ \\
\hline 12.15 & Collins, J., Baer, B. and Weber, E.J. & $\begin{array}{l}\text { SEXUAL SELECTION, CONSPICUOUS CONSUMPTION } \\
\text { AND ECONOMIC GROWTH }\end{array}$ \\
\hline 12.16 & Wu, Y. & TRENDS AND PROSPECTS IN CHINA’S R\&D SECTOR \\
\hline 12.17 & Cheong, T.S. and Wu, Y. & $\begin{array}{l}\text { INTRA-PROVINCIAL INEQUALITY IN CHINA: AN } \\
\text { ANALYSIS OF COUNTY-LEVEL DATA }\end{array}$ \\
\hline 12.18 & Cheong, T.S. & THE PATTERNS OF REGIONAL INEQUALITY IN CHINA \\
\hline 12.19 & Wu, Y. & $\begin{array}{l}\text { ELECTRICITY MARKET INTEGRATION: GLOBAL } \\
\text { TRENDS AND IMPLICATIONS FOR THE EAS REGION }\end{array}$ \\
\hline 12.20 & Knight, K. & $\begin{array}{l}\text { EXEGESIS OF DIGITAL TEXT FROM THE HISTORY OF } \\
\text { ECONOMIC THOUGHT: A COMPARATIVE } \\
\text { EXPLORATORY TEST }\end{array}$ \\
\hline 12.21 & Chatterjee, I. & $\begin{array}{l}\text { COSTLY REPORTING, EX-POST MONITORING, AND } \\
\text { COMMERCIAL PIRACY: A GAME THEORETIC } \\
\text { ANALYSIS }\end{array}$ \\
\hline 12.22 & Pen, S.E. & QUALITY-CONSTANT ILLICIT DRUG PRICES \\
\hline 12.23 & Cheong, T.S. and Wu, Y. & $\begin{array}{l}\text { REGIONAL DISPARITY, TRANSITIONAL DYNAMICS } \\
\text { AND CONVERGENCE IN CHINA }\end{array}$ \\
\hline
\end{tabular}

